\title{
Negative consequences of positive feedbacks in US wildfire management
}

\author{
David E Calkin ${ }^{1 *}$, Matthew P Thompson ${ }^{1}$ and Mark A Finney ${ }^{2}$
}

\begin{abstract}
Over the last two decades wildfire activity, damage, and management cost within the US have increased substantially. These increases have been associated with a number of factors including climate change and fuel accumulation due to a century of active fire suppression. The increased fire activity has occurred during a time of significant ex-urban development of the Wildland Urban Interface (WUI) along with increased demand on water resources originating on forested landscapes. These increased demands have put substantial pressure on federal agencies charged with wildfire management to continue and expand the century old policy of aggressive wildfire suppression. However, aggressive wildfire suppression is one of the major factors that drive the increased extent, intensity, and damage associated with the small number of large wildfires that are unable to be suppressed. In this paper we discuss the positive feedback loops that lead to demands for increasing suppression response while simultaneously increasing wildfire risk in the future. Despite a wealth of scientific research that demonstrates the limitations of the current management paradigm pressure to maintain the existing system are well entrenched and driven by the existing social systems that have evolved under our current management practice. Interestingly, US federal wildland fire policy provides considerable discretion for managers to pursue a range of management objectives; however, societal expectations and existing management incentive structures result in policy implementation that is straining the resilience of fire adapted ecosystems and the communities that reside in and adjacent to them.
\end{abstract}

Keywords: Wildfire suppression; Wildfire paradox; Wildland urban interface; Resilience

\section{Review}

In the past half century, wildland fire managers in the US has developed an increasingly sophisticated suppression response organization, including large aircraft, smoke jumpers, infrared mapping, satellite detection, computer dispatching, fire simulation, and nationwide coordination. Between 2011 and 2014, federal expenditures on suppressing large wildfires have exceeded \$1.5 each year (National Interagency Fire Center 2014), but wildfires are becoming larger and more expensive and damages to watersheds and communities are still rising. Do these outcomes evince success of a suppression-centric strategy? Are practical alternatives available? In this article we review the structure of US wildfire management organizations. Attention is given to the incentives for agencies as well as the public. Evaluation of incentives and consequences within the framework of

\footnotetext{
* Correspondence: decalkin@fs.fed.us

${ }^{1}$ Forestry Sciences Laboratory, US Forest Service Rocky Mountain Research

Station, 800 East Beckwith, Missoula, MT 59801, USA

Full list of author information is available at the end of the article
}

actuarial risk assessment reveals that modern wildfire problems derive from the self-reinforcing cycle of countereffective actions.

\section{Historical context}

Wildfire has been long recognized as an essential and perpetuating process in the ecology of most North American forests and rangelands (Wright 1982). In some places today, such as the southern states fire has an accepted presence and is seen as a vital management tool (Fowler and Konopik 2007). By contrast, the western US contributes most of the suppression costs and damages and policies emphasizing fire exclusion have come to be regarded as both feasible and desirable. The evolution of current policy is well documented by historians (see for example Pyne 1982). Consequences of fire exclusion can be generalized from detailed ecological research that shows low and mid-elevation forests with relatively frequent fires have become denser and spatially continuous and support large crown fires (Hessburg et al. 2005).

\section{实}


Forests with long-interval fire regimes show changes in landscape patterns and proportions of age and structure (Keane et al. 2002). Grassland and shrubland ecosystems have also experienced changes in fire regime in the past century, with some losing diversity without fire (Brockway et al. 2002) and some because of increased fire frequency after invasion by exotic annual grasses that increase continuity and flammability under a wide range of weather conditions (Knapp 1996).

Perhaps the strongest evidence of changes to fire regimes in forested ecosystems caused by attempted fire exclusion comes from comparisons between contemporary management and direct accounts of management at the close of the $19^{\text {th }}$ century. The series of Annual Reports to the Department of Interior regarding the forest reserves from 1897-1905 offers a broad set of descriptions of forests and fire activities throughout the west and depicts startling contrasts with contemporary conditions. In California, for example, the 257,314 acre Rim Fire in 2013 (Lydersen et al. 2014) and the 97,717 acre King fire in 2014 burned as extensive crown fires through multiple elevation zones in the west-central portion of the Sierra Nevada mountains. Little more than a century before, however, Sudworth (1900) described a universal surface fire regime in forests of the Stanislaus and Tahoe Forest Reserves:

"The fires of the present time are peculiarly of a surface nature, and with rare exception there is no reason to believe that any other type of fire has occurred here. Parts of the older forests may have had a deep humus, which, being burned, would have destroyed timber by deep burning at the roots. But there being no humus at the present time, deep burning is impossible. The tree roots are for the most part buried deep in the crevices of bare rock, in gravel, sand, or shale, over which surface fires run annually without the slightest direct injury to the roots. Barring the debris left from timbercutting, the only food for these fires is the scanty fall of pine and fir needles, irregular patches of low conifer seedlings, and chaparral. In general, these materials limit the fires to surface burning" (Sudworth 1900).

The wholesale conversion of California forests from a surface fire regime to the modern infrequent crown fire (Show and Kotok 1924) occurred rapidly because fires were easily suppressed in those early fuel conditions and the high productivity of the California environment generated biomass quickly. The same trends are documented in low- and mid-elevation forests throughout the west (Keane et al. 2002; Hessburg et al. 2005; Pechony and Shindall 2010) but more slowly where productivity is lower (e.g. Colorado). In California, both factors encouraged foresters to think that fire could be excluded to grow more trees. Several decades later, Show and Kotok (1924) recorded effects of pursuing total fire exclusion:

"The establishment of the national forests in California, beginning as early as 1891, thus found forest burning an established practice. The idea that fires could be excluded entirely from millions of acres was generally regarded as preposterous and the most gloomy pictures were drawn of any such attempt. It was claimed that the uncontrollable crown fire was to be expected as the inevitable consequence of allowing ground cover and litter to accumulate. Thus, in the early years of protection of the national forests, the forests were still open as a result of the repeated fires of the past. The great outbreak of incendiarism and agitation for light burning did not come until later. As fire protection became an accomplished fact and the young growth began to fill up the open forest, the amount of inflammable material in the forests increased greatly."

Even with the advantage of witnessing firsthand the fuel and fire transformations, advocates for prescribed fire ("light burning") in the early 1900s had political difficulties reversing the trend because of the primacy of timbermanagement perspectives. Show and Kotok (1924) detail considerable evidence against early attempts to reintroduce frequent surface burning resulting in damage to timber and killing of tree reproduction. Nowadays, forest scientists and ecologists find these historical reports convincing evidence that attempted "protection" paradoxically caused forest destruction. Protection really was not "an accomplished fact" because wildfire could not be permanently deferred - only changed in character when it inevitably occurred. However, the existing incentives and organizational structure maintain this pattern of wildfire suppression response.

\section{Modern context}

Increasing wildfire activity, damage, and associated management cost within the US (Williams 2013) is driven by a complex web of social and ecological factors (Spies et al. 2014). Although disturbance is a critical characteristic of many ecological systems that have evolved with wildfire and human communities over the past several millennia (Stewart 2002), fire control remains the dominant management paradigm in the western US beginning in the $20^{\text {th }}$ century (Pyne 1982). Now, after more than a century of aggressive suppression the wildfire paradox (Arno and Brown 1991) is fully realized in most western forests. Reduced wildfire on the landscape has led to increased fuel loading and continuity on most forested landscapes in the western US. Under extreme but not infrequent conditions suppression is less successful particularly where fuels have 
accumulated (Arno and Brown 1991; Stephens and Ruth 2005) and impacts to natural and developed resources are greater. Essentially, through our management efforts we have changed the distribution of fire behavior to only the most extreme. Public land management agencies have responded to this increase in wildfire activity with increased effort to remove wildfire from the landscape through aggressive initial attack (IA) and extensive wildfire suppression efforts aimed at minimizing the size of and/or damage from those few fires that escape IA. Although IA rates appear to be relatively stable (averaging between 97 and 99 percent successful, Calkin et al. 2005), the amount of area burned from large fires has been increasing over the last several decades (see Figure 1) further prompting increased wildfire suppression effort.

A report by USDA Forest Service (2014) documents the financial scale of wildfire management activities including large fire suppression and associated consequences to the Agency's budget. Large wildfire suppression activities by US Federal agencies have cost nearly $\$ 24$ billion between 2000 and 2013 (adjusted to 2013 US\$). This does not include state and local government costs nor does it include federal cost for pre-suppression activities (planning, equipment and labor acquisition), wildfire initial attack, or hazardous fuels management. The USDA Forest Service maintains the largest federal wildfire organization representing approximately 70 percent of all federal expenditures on wildfire management. In 1995 wildfire related expenses represented 17 percent of the US Forest Service's appropriated funds, by 2014, 51 percent of the appropriated funds were related to wildfire management. This increased demand for wildfire suppression has created a budgetary cycle where ever increasing demands for wildfire suppression funding come at the cost of other public land management programs, some of which are intended to directly reduce future wildfire damage. During this period of time, the Agency's budget has not increased commensurately with the rise in wildfire management expenditures. Thus other major budget items have experienced significant reduction; for example vegetation and watershed management (22 percent reduction), facilities (67 percent reduction), roads (46 percent reduction), and deferred maintenance (95 percent reduction) (USDA Forest Service 2014). Increasing wildfire damage to human and ecological systems compromise public land management agencies such as the USDA Forest Service's ability to maintain key ecological function and the provisioning of ecosystem services.

\section{Drivers of wildfire response}

Although a number of recent articles have focused on the application of active forest management of fire adapted ecosystems to improve social and ecological conditions (see for example Franklin et al. 2014; Spies et al. 2014) we examine the drivers of wildfire management response and

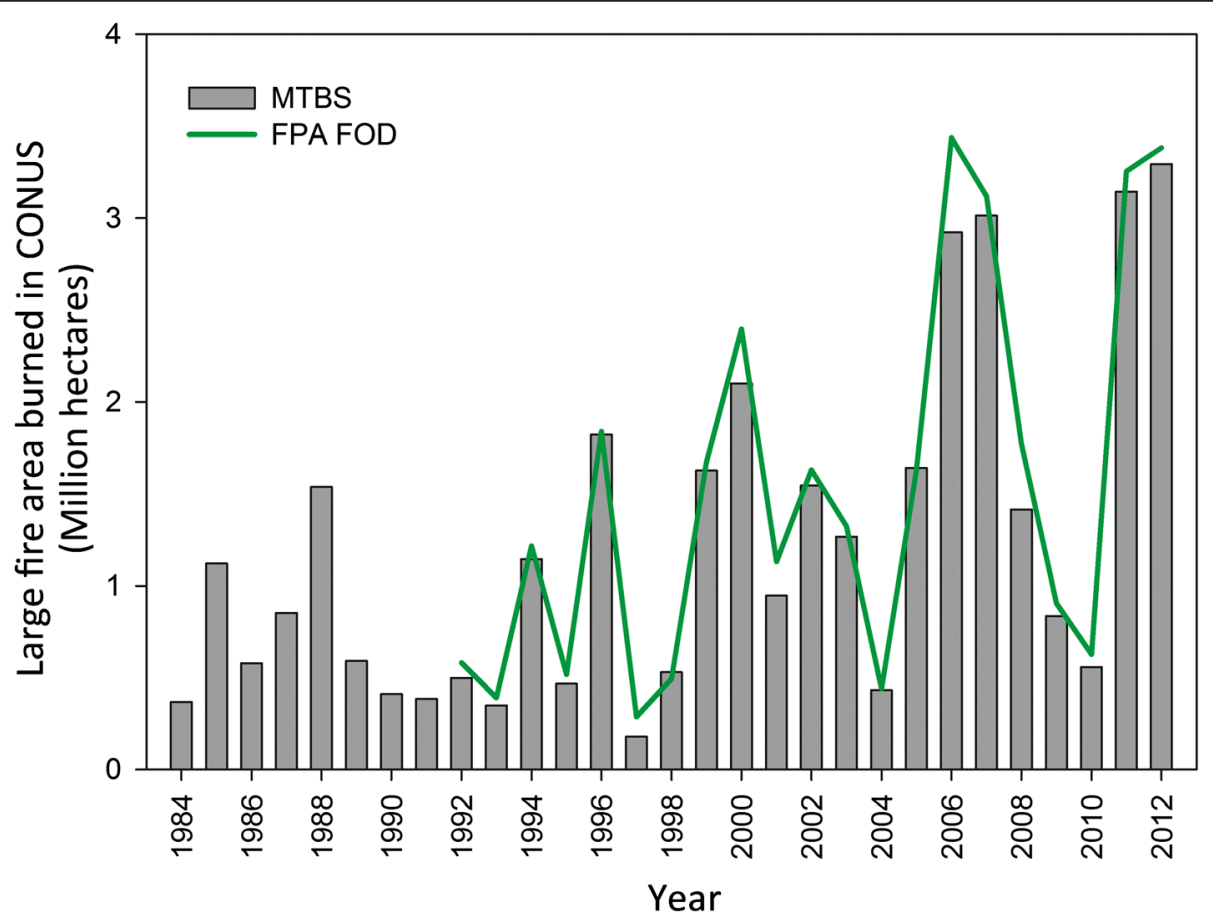

Figure 1 Estimates of area burned by large wildfires in the contiguous United States (CONUS), 1984-2012. A large wildfire is defined here as $\geq 405$ ha in the Western US, $\geq 203$ ha in the Eastern US. Estimates for 1984-2012 (bars) are based on large perimeters mapped as part of the Monitoring Trends in Burn Severity (MTBS) project (Eidenshink et al. 2007). An additional set of estimates for 1992-2012 (line) is based on records of wildfires $>405$ ha included in the Fire Program Analysis Fire-Occurrence Database (Short 2014). 
implications to the implementation of wildfire policy and associated consequences. Figure 2 demonstrates primary managerial, social, and ecological drivers of wildfire management response in both the fire season that is currently being managed and how these factors affect the trajectory of wildfire risk and associated management response into the future. In this simplified framework, wildfire risk is jointly determined by the landscape hazard and the susceptibility of values-at-risk (Finney 2005). Hazard reflects forest and fuel conditions, and is typically quantified in terms of the likelihood and intensity of wildfire (Scott et al. 2013). The susceptibility of resources (e.g., habitat) and assets (e.g., homes) is often framed as potential loss, however for some resources fire can lead to improved ecological condition (Scott et al. 2014). The critical point of this figure is that all of the primary drivers of wildfire suppression response, both within the current season and the trajectory for future response, drive an increasing suppression response with consequences to the trajectory of future wildfire risk and associated loss.

Wildfire risk drives managers to attempt to suppress wildfires to reduce potential resource loss from the current event. Economic efficiency suggests that the cost of the last resource assigned to manage a wildfire should be equal to the reduction in net loss from the assignment of that resource. Although US federal wildland fire policy does not specifically direct managers to seek economically efficient strategies it does dictate that the cost of the management response should be commensurate with values to be protected (Interagency Working Group 2001). Despite guidance on the application of economic principles to wildfire management there are many reasons to believe that current suppression response is excessively risk averse. Specifically, the loss of value to resources due to wildfire may be less than the cost of the suppression response developed to protect those values. In a choice survey of federal wildfire managers Calkin et al. (2013) demonstrated that, all else equal, mangers were more likely to select wildfire suppression strategies with higher suppression costs after accounting for potential risk to homes, ecological values, and firefighter exposure.

Wildfire management response that promotes increased application of wildfire may be hindered by societal expectations of the suppression only orientation of past management practices (Steelman and McCaffrey 2013). Socio-political influence from politicians, landowners and the affected public on fire managers increases the level and cost of suppression response (Canton-Thompson et al. 2008). For example Donovan et al. (2011) demonstrated that per area cost of

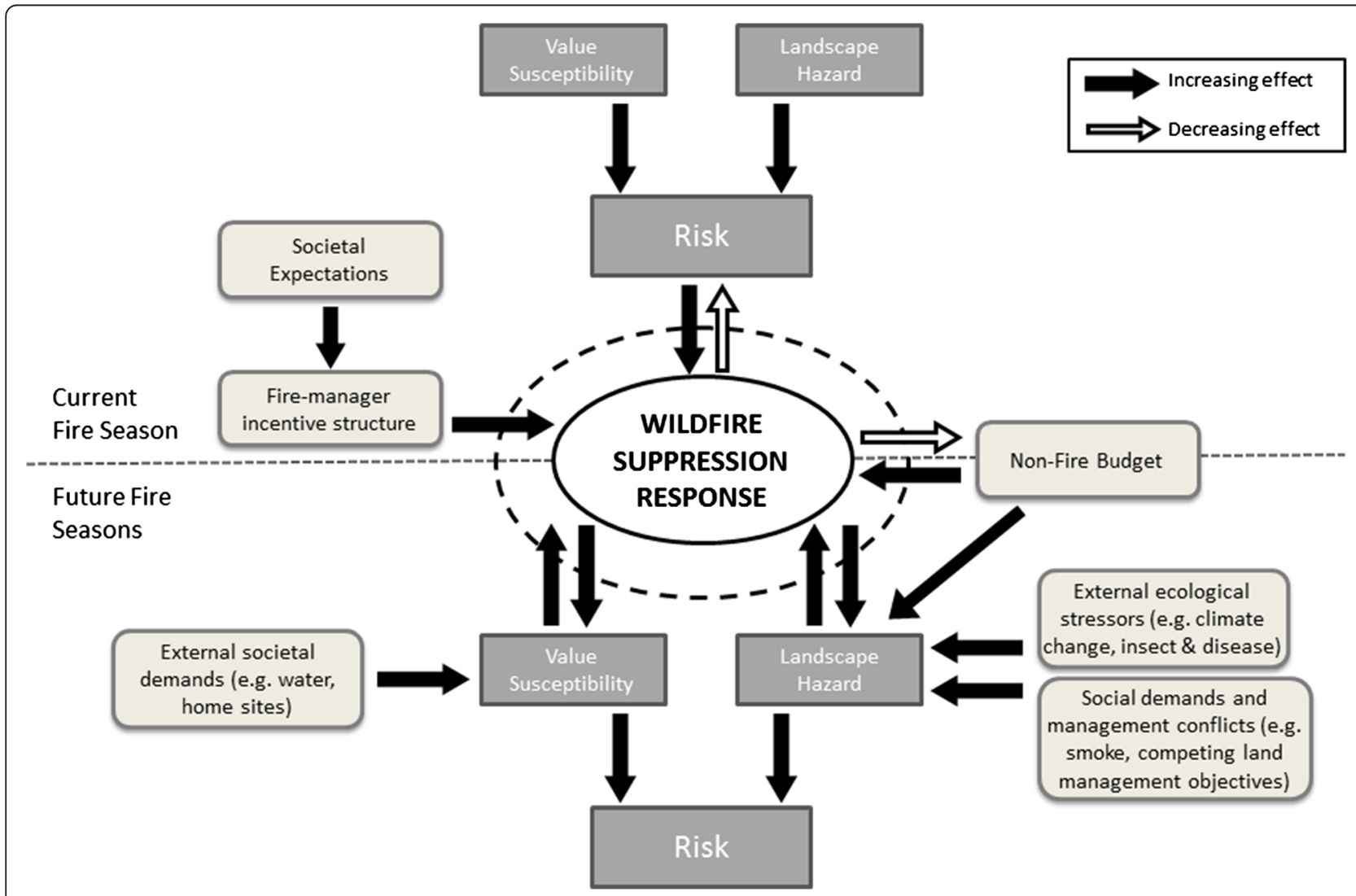

Figure 2 Conceptual model of managerial, social, and ecological drivers of near-term and future wildfire management response. 
managing a wildfire was positively associated with the seniority of the congressional representative of the district in which the fire occurred and the amount of media coverage. In addition to the positive socio-political influence on the level of suppression response, the existing incentive structure and budget process provides only weak feedback in terms of internalizing the impact of wildfire suppression spending on decision makers charged with managing wildland fires (Donovan and Brown 2005; Thompson et al. 2013).

Further, federal fire managers exhibit decision biases and heuristics that are common to environments characterized by significant complexity and uncertainty, which can lead to suboptimal decisions and outcomes (Thompson 2014). When selecting strategies, fire managers have displayed the discounting bias (overemphasizing short-term risk reduction over longer-term considerations), the status quo bias (reverting to suppressing all fires relative to allowing fires to burn for ecological considerations), and the loss aversion bias (preferring safe options when consequences are framed as potential gains) (Wilson et al. 2011). Fire managers can also exhibit systematic errors in estimating and interpreting probabilistic information (such as underestimating likely outcomes while overestimating rare events), which can lead to poor risk management (Donovan and Noordijk 2005; Maguire and Albright 2005; Wibbenmeyer et al. 2013). Knowledge gaps and limited understanding of the socioeconomic and ecological consequences of fire engender further uncertainty when evaluating alternative courses of action (Thompson and Calkin 2011; Venn and Calkin 2011; Hyde et al. 2013) which may lead to managers pursuing aggressive suppression strategies under conditions with low levels of risk to valued assets (Wibbenmeyer et al. 2013).

Budgetary implications of spending on wildfire suppression have both immediate and long term negative consequences. Over recent years, spending on current wildfire seasons have frequently resulted in transferring budget away from other land management activities including those that could reduce landscape hazard such as fuel reduction treatments. However, it has become increasingly clear that the impact of increasing fire management costs on non-fire related expenditures may have more significant long term implications to the agencies' ability to meet their land management objectives than issues associated with in season fund transfers (USDA Forest Service 2014). In 2014 there has been an active effort within the US Congress and Obama administration to fund a portion of wildfire management expenditures similar to current natural disaster funding under the Federal Emergency Management Agency. By funding wildfire suppression for large wildland fires under such an approach the uncertainty associated with changes in annual fire expenditures due to different levels of fire activity and the downward funding trends on non-fire programs would be simultaneously addressed.

Under certain conditions wildland fire can promote significant ecological benefits and reduce the risk that high intensity fires will spread to areas of high value into the future (Noss et al. 2006). Although there is broad scientific consensus regarding the need for more fire on the landscape, almost all fire management entities within western states require and promote aggressive suppression of all wildfires. Within federal land management agencies knowledge and experience allowing wildfires to burn for beneficial effects has been growing over time and is established within the land management objectives of the different federal agencies. The published 2009 interpretation of US Federal Wildfire Policy (Fire Executive Council 2009) expanded the opportunity of managers to better consider beneficial aspects of wildfire when determining fire management strategies. However, achieving increased beneficial wildfire opportunities in practice has been far more challenging. Existing land and fire management plans have not sufficiently considered the role of existing beneficial use on future fire management opportunities (Doan et al. 2006; Calkin et al. 2011) and managers are subject to a status quo bias that makes them reluctant to select beneficial use strategies when full suppression has been previously established (Wilson et al. 2011). Despite increased scientific recognition of the need to allow wildfire in fire adapted ecosystems to burn for resource benefit and examples of successful wildland fire use programs suppression persists as the dominant fire management strategy.

\section{Landscape hazard \& value susceptibility}

Concurrent with the increased wildfire activity has been a substantial increase in residential development within the Wildland Urban Interface (WUI) (Theobald and Romme 2007). Despite the vigorous fire suppression near human communities (Gebert et al. 2007; Liang et al. 2008; Gude et al. 2013) the number of homes destroyed by wildfire continues on an upward trend. Wildfire-related insured losses in the United States in the 10 year span of 2002 to 2011 totaled $\$ 7.9$ billion (US). This represents a $\$ 6.2$ billion increase over the previous decade (Haldane 2013). Although wildfire risk reduction near the WUI has been targeted by public land management agencies, failure to consider the conditions under which loss occurs may limit the effectiveness of these investments in reducing residential property loss (Calkin et al. 2014). Further, certain landscape conditions and fire regimes are more amenable to fuel treatments and community capacity and institutional factors have a strong influence on social acceptability (Spies et al. 2014) and capacity to act thus requiring context specific risk reduction strategies (Moritz et al. 2014).

A primary tool for land managers to address increasing landscape hazard is hazardous fuels reduction treatments. Within the federal fuel treatment programs a majority of 
funding is directed towards treatments within the WUI. However, it has been well demonstrated that residential home destruction is primarily determined by the immediate surrounding $(30-60 \mathrm{~m})$ of the home, known as the home ignition zone (HIZ) (Cohen 2000, 2010). The HIZ principally determines home ignition potential during extreme wildland fire behavior and includes the home construction characteristics and its immediate surroundings, in most case largely on private land. Focusing solely on wildland vegetation without consideration and mitigation of HIZs furthers the illusion of WUI protection without homeowner engagement. Prioritizing public investments on fuel reduction efforts and wildfire suppression in and around the WUI reduces the true cost of housing location decisions thus incentivizing development in high wildfire hazard areas and need for increased future investment (Cleetus and Mulik 2014). Significant progress has been made in the development of community based wildfire protection plans however, land use zoning restrictions and requirements to reduce structure ignitability remain contentious issues (Jakes et al. 2011).

Beyond the increasing risk to human development, the increasing population within the western US drives increased demand for municipal water. In the western US, half of all water originates on lands administered by the US Forest Service (Brown et al. 2008). Severe wildfires can result in significant and costly impacts to municipal watersheds, ranging from increased sedimentation to increased likelihood of debris flows to damage of water delivery infrastructure and interruption of service, prompting additional interest in risk mitigation options (Warziniack and Thompson 2013; Tillery et al. 2014).

Prescribed fire has been well recognized within the scientific literature (Hann and Bunnell 2001; Graham et al. 2004; Martinson and Omi 2013) as a fuel modification and restoration technique that is highly effective at mitigating wildfire behavior. Hann and Bunnell (2001) proposed that fire and land management planning focus fuel treatment efforts on reducing the current level of departure of forested lands from their historical fire regime to address increasing wildfire concerns within the United States. Although challenges emerged to define and manage towards departure many of the original concepts are present in the current emphasis on restoring the condition of dry frequent fire pine forests in the western US. There is general scientific agreement that fuel loading and stand density have reduced the resilience of these forests by making them more susceptible to wildfire and insect and disease outbreaks (Allen et al. 2002; Hessburg et al. 2005; Noss et al. 2006). In general society has a preference for active management to address wildfire risk and degrading ecological conditions of fire adapted forests (McCaffrey et al. 2012). However, societal factors such as inadequate funding, conflicts among objectives and priority of resource values as well as limited public understanding have created significant delay in the implementation of these programs to restore forest resilience to fire (Franklin et al. 2014; Rideout et al. 2014). Additionally, the current scale of fuel treatment is far less than required to achieve landscape resilience (North et al. 2012). Along with societal barriers, conflicting priorities within land management plans and mandates within environmental regulations such as the Clean Air Act and the Endangered Species Act limit the ability to achieve substantial reduction of wildfire hazard (Calkin et al. 2011).

\section{Future fires and maladapation to risk}

Pyne (2011) summarizes the condition of fire management in the US as follows: "What is striking about the American style of fire is how technically robust it is, and how politically dysfunctional and inept in practice so much of it has become." In the face of the increasing wildfire risk and highly damaging events, political responses have typically focused on increasing the suppression response (Busenberg 2004). Wildfire suppression without a commensurate program to address the fuel accumulation resulting from the aggressive suppression policy represents a major policy error in federal fire management (Busenberg 2004). This policy error was propagated with mounting impacts as federal land management agencies acquired new resources and influence to reinforce the established institutional wildfire management approach of aggressive suppression. This self-reinforcing action has caused the impacts of the original policy failure to gradually escalate over time. The selfreinforcing nature of aggressive suppression response is not unique to wildfire management in the US and has been demonstrated using a system dynamics modelling approach to wildfire management in Portugal (Collins et al. 2013). Further the authors identified three primary reasons why transformation of this self-reinforcing and costly behavior is unlikely to occur organically due to 1) managerial incentive structures focusing on short term results, 2) challenges to identifying when mitigation resulted in damages averted and the inability to take credit, and 3) the financial interests of established firefighting organization in maintaining current policy. Spies et al. (2014) argued that challenges such as heterogeneity in wildfire behavior and effects, human behavior and values and weak landscape feedbacks to humans create a highly complex system that may lead to maladaptive behavior and unintended consequences of fire policy.

State agencies charged with wildfire management typically have less flexibility in their suppression policy. With few exceptions most western state agencies are directed to suppress wildfires at the smallest size feasible. Further, as many of the states have experienced highly damaging events the typical response has been to increase the pre-established emphasis on aggressive suppression of all wildfires. For example, the state of Colorado experienced several highly 
damaging wildfire events including the Fourmile Canyon Fire of 2011 (169 homes destroyed, zero fatalities), High Park Fire (259 homes destroyed, one fatality), Waldo Canyon Fire of 2012 (346 homes destroyed, zero fatalities), and the Black Forest Fire of 2013 (486 homes destroyed, two fatalities). Additionally, the Lower North Fork Fire in 2012, an escaped prescribed fire conducted by the Colorado State Forest Service, burned 23 homes and killed three people. In a response to this event responsibility for wildfire management was moved from the Colorado State Forest Service to the Department of Public Safety. Additionally, the state has implemented new restrictions and additional requirements for the application of prescribed burning and approved a bill to fund a fleet of state owned aerial wildfire suppression resources. The intent of the investment in aerial resources was stated as follows: "Keep all wildfires with values at risk smaller than 100 acres and to suppress all fires in Wildland Urban Interface (WUI) areas at less than ten acres, 98\% of the time." (Colorado Department of Fire Prevention and Control 2014). This demonstrates an instance when a wildfire agency defines target conditions of preparedness and capability below the large fire-disaster levels. Highly damaging wildfires such as the Waldo Canyon, Fourmile, and Black Forest Fires occur during the 2 percent of events where suppression is not effective (Calkin et al. 2014).

\section{Breaking the cycle}

Policies and actions to reduce the cycle of ever increasing wildfire suppression effort, management costs, and resource losses will be challenging to implement. Inertia of the existing social systems habituated by the current management paradigm is entrenched in social expectations and agencies' cultures. Significantly reducing fuel loading associated with the current condition of the forested landscape through active management would require huge capital investment and conflict with other existing environment regulations. The 2009 Interpretation of Federal Wildfire Policy opened up opportunities to manage wildfires for resource benefit within the wildfire suppression program. However, in recent years managing fires by allowing them to burn under certain conditions to achieve resource benefit has proved challenging (Hubbard 2012).

Concepts of system resilience may provide an interesting lens to examine current challenges in wildfire management. Resilience thinking extends previous efforts for sustainable resource management such as ecosystem analysis and adaptive management by further emphasizing the critical linkages between social and ecological systems (Rist and Moen 2013). Resilience can be defined as "the capacity of a system to absorb disturbance, re-organize, and keep functioning in much the same way as before" (Walker 2013). Managing towards resilience can be characterized as actions that maintain a desirable state or transform existing structure to achieve a more desirable state (Walker et al. 2006). Resilience by itself at one spatial and temporal scale does not imply that a system is in a beneficial state. Many types of ecological or social systems may be highly resilient, but result in reduced ecological condition or social wellbeing. For example cheat grass invaded ecosystems in the Western US are highly resilient to disturbance. Thus, resilience requires looking at systems at different scales - achieving resilience at one level may require transformation at other levels (Walker 2013). The current wildfire management policy in the US has slowly evolved over the last century but has been relatively consistent; aggressively suppress all wildland fires. Altering the trajectory of risk will require system transformation. There are several possible trajectories for the future of wildfire management. As describe earlier, maintaining the status-quo has obvious implications in terms of increasing wildfire risk, increased damage and loss due to wildfire, along with significant consequences to the structure and functioning of public land agencies and their ability to meet their core missions. Alternatively, wildfire management could be driven to transform by the public demanding an alternative wildfire management approach and/or by transformative actions initiated within federal agencies themselves.

Transformation is frequently initiated by a series of highly salient events that create a dramatic shift in public expectations and demands from existing social structures. The scale of event that would lead to US society demanding a transformation of current wildfire policy remains unknown. O'Neill and Handmer (2012) suggest that the Black Saturday events in Victoria and New South Wales Australi, where 172 civilians were killed represent such a transformative event. The significant media and public attention caused by the scale of loss of life resulted in a critical examination of bushfire management in general and more specifically the implication of the Stay and Defend Policy and prescribed fire program. Despite the increased political and media focus associated with the events of Black Saturday, there is some concern that homeowner response to wildfire may not have changed and that existing public behavior has not transformed in light of these events. Specifically, approximately one-third of respondents to a survey targeted at Australian households at risk from bushfire just one year after the Black Saturday fires was to wait and see what happens during the fire, but leave if threatened by the fire (Rhodes 2011). Essentially this represents a strategy of evacuating late which is in complete contrast to the stated policy in Australia. Thus, it is probably too early to determine if in fact the Black Saturday events result in a transformation of Australian fire management policy and implementation.

Systems can adaptively transform in ways that allow the system to better handle changing conditions, stress, hazards, 
risk or opportunities in the future (see Smit and Wandel 2006). Such an adaptive transformation would require a range of alternative approaches to be pursued including increased levels and improved efficiency of fuel reduction treatments, alternative management structures that encourage less aggressive suppression strategies that incur broader ecological outcomes and reduce future wildfire hazard, improved risk sharing among public land managers and interface communities through more fire resistant structure design, modified fuel conditions adjacent to communities, and zoning restrictions of further development within the most fire prone areas (Cleetus and Mulik 2014).

If wildfire suppression funding was handled under a disaster relief funding mechanism, continued stress on fuel reduction funding and other active management that may reduce wildfire risk could be alleviated. However, unless the scale of fuels funding were dramatically increased along with relief from conflicting environmental regulations it is unlikely that the scale of fuel modification will be accelerated to reduce the wildfire hazard in the short term. Therefore, although it does not appear that fuels treatments activities could replace wildfire in achieving ecological resilience of forested ecosystems in the western US, they will likely play a critical role in positive adaptive management response. Recognizing this reality, Reinhardt et al. (2008) identified the importance of fuel treatment in creating landscapes where fire can occur without devastating consequences; recognizing that we cannot, nor should not expect fuel treatment programs to replace naturally occurring wildfire. Achieving this objective requires focusing treatments such that, in the event of a wildfire, spread and intensity is such that significant loss to highly valued resources is minimized.

Reduced fuel loading and improved forest health is a necessary but not sufficient condition for reducing wildfire risk. The range of ecosystem conditions, fire regimes and land uses suggests a one size fits all approach to wildfire and fuels management is neither desirable nor feasible (Keeley et al. 2009). In many communities fuels reduction activities may be quite challenging due to a range of factors such as rapid regrowth, high management cost, and complex ownership patterns. Further in some areas such as lodgepole pine forests in the interior west, the natural fire regime is infrequent high intensity fire and reasonable fuels reduction treatments are limited. Under these circumstances reducing the susceptibility of highly valued resources to wildfire may be more appropriate. As Dombeck et al. (2004) state, "communities need to shoulder greater responsibility for regulating sprawl and for encouraging proactive efforts by homeowners to reduce the risk of home ignition during wildfire."

Within the Southeastern US a culture of aggressive prescribed fire has developed gradually over the past 50 years with the reduction of fire hazard as the primary management objective across ownerships (Fowler and Konopik 2007). By maintaining fuel conditions through regular burning and the development of a community of practitioners forest lands are generally maintained in a condition of relatively low hazard with management cost far less on a unit basis than equivalent treatments in the Western US. For example, National Forest land in the southeastern US (US Forest Service Region 8) represents only 10 percent of the total Forest Service land base, but between 2007 and 2012 the region accounted for almost 70 percent of the Agency's prescribed burned area while accounting for only 6 percent of large fire suppression costs (USDA Forest Service internal reports).

By allowing naturally ignited wildfires to burn to achieve resource benefit (formerly known as wildland fire use), fuel conditions may be improved thus reducing wildfire risk in adjacent areas. The reduced wildfire risk may further increase the area and weather conditions where wildfires need not be aggressively suppressed. In several wilderness areas throughout the Western US, such as the Selway-Bitteroot and Bob Marshall Wilderness Areas in Montana, and the Gila Wilderness in New Mexico, once reduced fuel loading and barriers to fire spread associated with past fire scars have been achieved, wildfire can play a role in maintaining these landscapes (Teske et al. 2012; Parks et al. 2014). Despite the critical role past fire scars have played in the suppression of large fires (Graham 2003; Cochrane et al. 2012), extensive application of the use of naturally ignited wildfires has not yet been well demonstrated outside large wilderness areas. Recognition that fire exclusion is neither desirable nor possible in many regions of the country is an essential (Moritz et al. 2014) and will be a critical component of any effort to transform wildfire management.

\section{Conclusions}

Examination of ecological and human community resilience in fire adapted ecosystems suggests a social ecological system that is under considerable stress. Increasing wildfire hazard due to fuel accumulation and climate related stressors and increasing vulnerability of developed residential communities and natural resource values suggest a future of increasing risk and management cost unless the current management paradigm is transformed. For transformation to succeed it will require increased recognition of the consequences associated with the current paradigm, social acceptance of alternative fire management strategies, and alteration of the culture of public agencies charged with wildfire suppression. Specifically actions include: 1) enhanced risk sharing among affected partners; 2) modification of managerial incentive structures and enhanced training; 3) land management treatments that directly address local risk factors and align with broad risk reduction 
strategies; 4) reduction of the uncertainty around outcomes from less aggressive suppression response through improved decision support; and 5) enhanced consideration of long term impacts of current decisions (visioning).

Fortunately, just like the current wildfire suppression paradox, many of the necessary changes are themselves self-reinforcing. The self-reinforcing nature of the use of fire to achieve land management objectives has been well demonstrated on selected public lands (Parks et al. 2014) and the Southeastern US has effectively used prescribed burning to lower wildfire risk and mitigation costs.

A one size fits all approach to reducing wildfire risk does not exist. Each high risk landscape will require a suite of actions to modify the trajectory of increasing suppression demand and loss. For society to demand transformation of the current wildfire management paradigm some sort of tipping point event may need to occur. However, adaptive transformation where public agencies working alongside private citizens challenge the supremacy of the existing wildfire suppression model in favor of long term economically efficient risk mitigation strategies is possible.

\section{Competing interests}

The authors declare that they have no competing interests.

\section{Authors' contributions}

DC developed the conceptual model and drafted the manuscript. MT contributed content on risk assessment and decision science and manuscript editing. MF provided wildfire historical context and review of wildfire behavior along with manuscript editing. All authors read and approved the final manuscript.

\section{Author details}

${ }^{1}$ Forestry Sciences Laboratory, US Forest Service Rocky Mountain Research Station, 800 East Beckwith, Missoula, MT 59801, USA. ${ }^{2}$ Fire Sciences Laboratory, US Forest Service Rocky Mountain Research Station, 5775 Highway 10 West, Missoula, MT 59808, USA.

Received: 31 October 2014 Accepted: 26 March 2015

Published online: 14 April 2015

\section{References}

Allen CD, Savage M, Falk DA, Suckling KF, Swetnam TW, Schulke T, Stacey PB, Morgan P, Hoffman M, Klingel JT (2002) Ecological restoration of southwestern ponderosa pine ecosystems: a broad perspective. Ecol Appl 12:1418-1433

Arno SF, Brown JK (1991) Overcoming the paradox in managing wildland fire in western wildlands. University of Montana, Montana Forest and Conservation Experiment Station, Missoula, MT, pp 40-46

Brockway DG, Gatewood RG, Paris RB (2002) Restoring fire as an ecological process in shortgrass prairie ecosystems: initial effects of prescribed burning during the dormant and growing seasons. J Environ Manage 65(2):135-152

Brown TC, Hobbins MT, Ramirez JA (2008) Spatial distribution of water supply in the Coterminous United States. J Am Water Resour As (JAWRA) 44(6):1474-1487

Busenberg G (2004) Wildfire management in the United States: the evolution of a policy failure. Rev Policy Res 21(2):145-156

Calkin DE, Gebert KM, Jones JG, Neilson RP (2005) Forest Service large fire area burned and suppression expenditure trends. 1970-2002. J For 103(4):179-183

Calkin D, Finney MA, Ager AA, Thompson MP, Gebert KG (2011) Progress towards and barriers to implementation of a risk framework for Federal wildland fire policy and decision making in the United States. For Policy Econ 13(5):378-389
Calkin DE, Venn TJ, Wibbenmeyer MJ, Thompson MP (2013) Estimating US federal wildland fire managers' preferences toward competing strategic suppression objectives. Int J Wildland Fire 22(2):212-222

Calkin DE, Cohen JD, Finney MA, Thompson MP (2014) How risk management can prevent future wildfire disasters. Proc Natl Acad Sci 111(2):746-751

Canton-Thompson J, Gebert KM, Thompson B, Jones G, Calkin D (2008) External human factors in incident management team decisionmaking and their effect on large fire suppression expenditures. J For 106(8):416-424

Cleetus R, Mulik K (2014) Playing with fire: how climate change and development patterns are contributing to the soaring costs of western wildfires., Available at: http://www.ucsusa.org/assets/documents/global_warming/playing-withfire-report.pdf. Accessed September 9, 2014

Cochrane MA, Moran CJ, Wimberly MC, Baer AD, Finney MA, Beckendorf KL, Eidenshink J, Zhu Z (2012) Estimation of wildfire size and risk changes due to fuels treatments. Int J Wildland Fire 21(4):357-367

Cohen JD (2000) Preventing disaster, home ignitability in the wildland-urban interface. J For 98(3):15-21

Cohen J (2010) The wildland-urban interface fire problem. Fremontia 38(2, 3):16-22

Collins R, de Neufville R, Claro J, Oliveira T, Pacheco A (2013) Forest fire management to avoid unintended consequences: a case study of Portugal using system dynamics. J Environm Manage 130:1-9

Colorado Department of Fire Prevention and Control (2014) Special report: Colorado Firefighting Air Corps., Available at: http://dfs.state.co.us/. Accessed October 30, 2014

Doan D, O'Lauglin J, Morgan P, Miller C (2006) Barriers to wildland fire use: a preliminary problem analysis. Int J Wilderness 12:36-38

Dombeck MP, Williams JE, Wood CA (2004) Wildfire policy and public lands: Integrating scientific understanding with social concerns across landscapes. Conserv Biol 18(4):883-889

Donovan GH, Brown TC (2005) An alternative incentive structure for wildfire management on national forest land. For Sci 51 (5):387-395

Donovan GH, Noordijk P (2005) Assessing the accuracy of wildland fire situation analysis (WFSA) fire size and suppression cost estimates. J For 103(1):10-13

Donovan GH, Prestemon JP, Gebert K (2011) The effect of newspaper coverage and political pressure on wildfire suppression costs. Soc Nat Res 24(8):785-798

Eidenshink J, Schwind B, Brewer K, Zhu Z, Quayle B, Howard S (2007) A project for monitoring trends in burn severity. Fire Ecol (Special Issue) 3:3-21

Finney MA (2005) The challenge of quantitative risk assessment for wildland fire. For Ecol Manage 211:97-108

Fire Executive Council (2009) Guidance for implementation of federal wildland fire management policy., http://www.nifc.gov/policies/policies_documents/ GIFWFMP.pdf. Last Accessed July 23, 2014

Fowler C, Konopik E (2007) The history of fire in the southern United States. Human Ecol Rev 14(2):165-176

Franklin JF, Hagmann RK, Urgenson LS (2014) Interactions between societal goals and restoration of dry forest landscapes in western North America. Landscape Ecol. DOI 10.1007/s10980-014-0077-0

Gebert KM, Calkin DE, Yoder J (2007) Estimating suppression expenditures for individual large wildland fires. West J Appl For 22:188-196

Graham RT (2003) Hayman Fire Case Study. Gen. Tech. Rep. RMRS-GTR-114. U.S. Department of Agriculture, Forest Service, Rocky Mountain Research Station, Ogden, UT, pp 1-32

Graham RT, McCaffrey S, Jain TB (2004) Science basis for changing forest structure to modify wildfire behavior and severity. USDA For. Serv. General Technical Report RMRS_GTR120

Gude PH, Jones K, Rasker R, Greenwood MC (2013) Evidence for the effect of homes on wildfire suppression costs. Int J Wildland Fire 22(4):537-548

Haldane M (2013) Insurers, government grapple with costs of growth in wildland urban interface. Insurance J. Available at: www.insurancejournal.com/news/ national/2013/08/15/301833.htm. Accessed September 9, 2014

Hann WJ, Bunnell DL (2001) Fire and land management planning and implementation across multiple scales. Int J Wildland Fire 10(4):389-403

Hessburg PF, Agee JK, Franklin JF (2005) Dry forests and wildland fires of the inland Northwest USA: contrasting the landscape ecology of the pre-settlement and modern eras. For Ecol Manag 211:117-139

Hubbard J (2012) 2012 Wildfire Guidance. Available at: https://www.documentcloud. org/documents/407523-2012-wildfire-guidance-memo-may-25.html. Accessed April 13, 2015

Hyde KD, Dickinson MB, Bohrer G, Calkin DE, Evers L, Gilbertson-Day J, Nicolet T, Tague C (2013) Research and development supporting fire effects prediction 
for fire and fuels management: status and needs. Int J Wildland Fire 22(1):37-50

Interagency Working Group (2001) Review and update of the 1995 federal wildland fire management policy. National Interagency Fire Center, Boise, ID

Jakes PJ, Nelson KC, Enzler SA, Burns S, Cheng AS, Sturtevant V, Williams DR, Bujak A, Brummel RF, Grayzeck-Souter S, Staychock E (2011) Community wildfire protection planning: is the Healthy Forests Restoration Act's vagueness genius? Int J Wildland Fire 20(3):350-363

Keane RE, Ryan KCVIT, Allen CD, Logan J, Hawkes B (2002) Cascading effects of fire exclusion in the Rocky Mountain ecosystems: a literature review. Gen. Tech. Rep. RMRS-GTR-91. U.S. Department of Agriculture, Forest Service, Rocky Mountain Research Station, Fort Collins, CO, p 24

Keeley JE, Aplet GH, Christensen NL, Conard SG, Johnson EA, Omi PN, Peterson DL, Swetnam TW (2009) Ecological Foundations for Fire Management in North American Forest and Shrubland Ecosystems. USDA For. Serv. General Technical Report: PNW-GTR-779

Knapp PA (1996) Cheatgrass (Bromus tectorum L.) dominance in the Great Basin Desert: history, persistence, and influences to human activities. Global Environ Chang 6(1):37-52

Liang J, Calkin DE, Gebert KM, Venn TJ, Silverstein RP (2008) Factors influencing large wildland fire suppression expenditures. Int J Wildland Fire 17:650-659

Lydersen JM, North MP, Collins BM (2014) Severity of an uncharacteristically large wildfire, the Rim Fire, in forests with relatively restored frequent fire regimes. Forest Ecol Manag 328:326-334

Maguire LA, Albright EA (2005) Can behavioral decision theory explain risk-averse fire management decisions? For Ecol Manag 211(1):47-58

Martinson EJ, Omi PN (2013) Fuel treatments and fire severity: a meta-analysis. USDA For Serv Research Paper RMRS_RP103www

McCaffrey S, Toman E, Stidham M, Shindler B (2012) Social science research related to wildfire management: an overview of recent findings and future research needs. Int J Wildland Fire 23:567-576

Moritz MA, Batllori E, Bradstock RA, Gill MA, Handmer J, Hessburg PF, Leonard J, McCaffrey S, Odion DC, Schoennagel T, Syphard AD (2014) Learning to coexist with wildfire. Nature 515(7525):58-66

National Interagency Fire Center (2014) Available at: https://www.nifc.gov/ firelnfo/firelnfo_documents/SuppCosts.pdf. Accessed February 23, 2015

North MP, Collins BM, Stephens SL (2012) Using fire to increase the scale, benefits, and future maintenance of fuels treatments. J For 110(7):392-401

Noss RF, Beier P, Covington WW, Grumbine RE, Lindenmayer DB, Prather JW, Schmiegelow F, Sisk TD, Vosick DJ (2006) Recommendations for integrating restoration ecology and conservation biology in ponderosa pine forests of the Southwestern United States. Restor Ecol 14(1):4-10

O'Neill SJ, Handmer J (2012) Responding to bushfire risk: the need for transformative adaptation. Environ Res Lett 7:014-018

Parks SA, Miller C, Nelson CR, Holden ZA (2014) Previous fires moderate burn severity of subsequent wildland fires in two large western US wilderness areas. Ecosystems. doi: 10.1007/s10021-013-9704-x

Pechony O, Shindall DT (2010) Driving forces of global wildfires over the past millennium and the forthcoming century. P Natl Acad Sci 107(45):19167-19170

Pyne SJ (1982) Fire in America. A cultural history of wildland and rural fire. Princeton University Press, Princeton, NJ, USA

Pyne S (2011) The wallow fire: a ruinous burn. Wildfire Magazine 2011:14-17

Reinhardt ED, Keane RE, Calkin DE, Cohen JD (2008) Objectives and considerations for wildland fuel Treatment in the Interior Western United States. For Ecol Manag 256:1997-2006

Rhodes A (2011) Opinion: ready or not? Can community education increase householder preparedness for bushfire? Aust J Emerg Manag 26:6-10

Rideout DB, Ziesler PS, Kernohan NJ (2014) Valuing fire planning alternatives in forest restoration: Using derived demand to integrate economics with ecological restoration. J Environ Manag 141:190-200

Rist L, Moen J (2013) Sustainability in forest management and a new role for resilience thinking. For Ecol Manag 310:416-427

Scott JH, Thompson MP, Calkin DE (2013) A wildfire risk assessment framework for land and resource management. Gen. Tech. Rep. RMRS-GTR-315. U.S Department of Agriculture, Forest Service, Rocky Mountain Research Station, Fort Collins, CO, USA, p 83

Scott JH, Helmbrecht DJ, Thompson MP (2014 [In Press]) Assessing the expected effects of wildfire on vegetation condition on the Bridger-Teton National Forest, Wyoming, USA. Research Note RMRS-RN-XX. U.S. Department of Agriculture, Forest Service, Rocky Mountain Research Station
Short KC (2014) A spatial database of wildfires in the United States, 1992-2011. Earth Syst Sci Data 6:1-27

Show SB, Kotok El (1924) The role of fire in the California pine forests. Bulletin, 1294U.S. Department of Agriculture, Washington, D.C, p 80

Smit B, Wandel J (2006) Adaptation, adaptive capacity and vulnerability. Global Environ Change 16(3):282-292

Spies TA, White EM, Kline JD, Fischer AP, Ager A, Bailey J, Bolte J, Koch J, Platt E, Olsen CS, Jacobs D, Shindler B, Steen-Adams MM, Hammer R (2014) Examining fire-prone forest landscapes as coupled human and natural systems. Ecol Soc 19 (3):9, http://dx.doi.org/10.5751/ES-06584-190309

Steelman TA, McCaffrey S (2013) Best practices in risk and crisis communication: Implications for natural hazards management. Nat Hazards 65(1):683-705

Stephens SL, Ruth LW (2005) Federal forest-fire policy in the United States. Ecol Appl 15(2):532-542

Stewart OC (2002) Forgotten fires: native Americans and the transient wilderness. Univ Oklahoma Press, Norman

Sudworth GB (1900) The Stanislaus and Tahoe Forest Reserves and adjacent territory. pp 499-561 In: Twenty First Annual report of the United States Geological Survey to the Secretary of the Interior 1899-1900. Charles D. Walcott, Director. Part V- Forest Reserves. Washington DC, USA

Teske CC, Seielstad CA, Queen LP (2012) Characterizing fire-on-fire interactions in three large wilderness areas. Fire Ecol 8(2):82-106

Theobald DM, Romme WH (2007) Expansion of the US wildland urban interface. Landscape Urban Plan 83(4):340-354

Thompson MP (2014) Social, institutional, and psychological factors affecting wildfire incident decision making. Soc Nat Res 27(6):636-644

Thompson MP, Calkin DE (2011) Uncertainty and risk in wildland fire management: a review. J Environ Manag 92:1895-1909

Thompson MP, Calkin DE, Finney MA, Gebert KM, Hand MS (2013) A risk-based approach to wildland fire budgetary planning. For Sci 59(1):63-77

Tillery AC, Haas JR, Miller LW, Scott JH, Thompson MP (2014) Potential postwildfire debris-flow hazards-A prewildfire evaluation for the Sandia and Manzano Mountains and surrounding areas, Central New Mexico: U.S. Geological Survey Scientific Investigations Report 2014-5161, p 24. with appendix, http://dx.doi.org/10.3133/sir20145161

USDA Forest Service (2014) The rising cost of fire operations: effects on the forest service's non-fire work., Available at: http://www.fs.fed.us/sites/default/files/ media/2014/34/nr-firecostimpact-082014.pdf. Accessed October 30, 2014

Venn TJ, Calkin DE (2011) Accommodating non-market values in evaluation of wildfire management in the United States: challenges and opportunities. Int J Wildland Fire 20(3):327-339

Walker B (2013) What is Resilience? Project Syndicate., http://www.projectsyndicate.org/commentary/what-is-resilience-by-brian-walker

Walker BH, Gunderson LH, Kinzig AP, Folke C, Carpenter SR, Schultz L (2006) A handful of heuristics and some propositions for understanding resilience in social-ecological systems. Ecol Soc 11(1):13

Warziniack T, Thompson M (2013) Wildfire risk and optimal investments in watershed protection. West Econ Forum 12(2):19-28

Wibbenmeyer MJ, Hand MS, Calkin DE, Venn TJ, Thompson MP (2013) Risk preferences in strategic wildfire decision making: a choice experiment with U.S. wildfire managers. Risk Analy 33(6):1021-1037

Williams J (2013) Exploring the onset of high-impact mega-fires through a forest land management prism. Forest Ecol Manag 294:4-10

Wilson RS, Winter PL, Maguire LA, Ascher T (2011) Managing wildfire events: risk-based decision making among a group of federal fire managers. Risk Anal 31:805-818

Wright HA (1982) Fire Ecology: United States and Southern Canada. John Wiley \& Sons, New York, NY, USA 